\title{
Analisis Nilai Ekonomis melalui Aspek Pasar dan Keuangan Pada Hotel Grand Sadurengas
}

\author{
Anton Ferry Ananda \\ Sekolah Tinggi Ilmu Ekonomi Kertanegara Malang \\ e-mail: anton_ferry@stiekma.ac.id
}

\begin{abstract}
Abstrak : Tujuan dari penelitian ini adalah menentukan nilai ekonomis pemanfaatan Hotel Grand Sadurengas dengan melihat aspek pasar dan aspek keuangan. Berdasarkan analisis SWOT posisi strategis Hotel Grand Sadurengas adalah grow and develop (tumbuh dan berkembang). Alternatif strategi yang dapat diterapkan kedepan pada masa mendatang yang terdiri atas strategi pengembangan pasar, penetrasi pasar dan pengembangan produk. Rata-rata market share untuk masing-masing hotel di Kabupaten Paser sebesar 4,17\% (100:24). Namun kalau dilihat dari keadaan hotel, maka Hotel Grand Sadurengas kondisinya lebih baik yang termasuk hotel kelas bintang tiga. Sementara hotel-hotel pesaingnya adalah kelas melati. Hal ini merupakan suatu keunggulan tersendiri dibanding dengan hotel pesaingnya. Dari keadaan tersebut tidaklah berlebihan kalau market share hotel Grand Sadurengas jelas lebih tinggi dari pesaingnya, yaitu sebesar $15 \%$. Penentuan $15 \%$ tersebut didasarkan pada rata-rata tingkat hunian kamar hotel di Kabupaten Paser, yaitu berkisar 21\%. Jadi kalau dibandingkan nilai market share terhadap jumlah kamar tersedia di Hotel Grand Sadurengas, maka hasilnya berkisar 21\%. Namun tidak menutup kemungkinan untuk masa yang akan datang market share nya berubah sesuai dengan perkembangan potensi pasar hotel di Kabupaten Paser serta strategi memenangkan persaingan yang dilakukan oleh Hotel Grand Sadurengas. Dari hasil analisis kelayakan (Payback Period, NPV dan IRR) maka dapat dikatakan bahwa investasi pada Hotel Grand Sadurengas layak untuk diteruskan, namun dengan tingkat keuntungan yang rendah dan pengembalian modal yang cukup lama yaitu 30 tahun. Selanjutnya, dari hasil analisis BEP bahwa tingkat penjualan kamar Hotel Grand Sadurengas agar tidak mengalami kerugian yaitu minimal sebesar 1.376 unit kamar setiap tahunnya.
\end{abstract}

.Kata kunci : SWOT, Payback Period, NPV, IRR, BEP

\section{Pendahuluan}

Otonomi daerah yang luas dan bertanggung jawab memberikan keleluasaan kepada daerah kabupaten/kota dalam mengurus kepentingan masyarakat sesuai dengan kondisi, potensi dan keanekaragaman wilayahnya. Otonomi luas bukanlah berarti kebebasan absolut bagi suatu daerah untuk menjalankan hak dan fungsi otonomi menurut kehendak daerah sendiri tanpa mempertimbangkan kepentingan daerah lain atau nasional. Batasan bagi keleluasaan otonomi daerah adalah keleluasaan daerah agar mampu berfungsi sebagai daerah otonom yang mandiri, berdasarkan azas demokrasi dan kedaulatan rakyat tanpa mengganggu stabilitas nasional dan keutuhan wilayah NKRI. Pemikiran meletakkan otonomi daerah pada tingkat wilayah yang paling dekat dengan rakyat (kabupaten/kota) memberikan makna untuk mendewasakan politik rakyat (democratization process) dan meningkatkan kesejahteraan rakyat.

Implikasi dari otonomi daerah adalah kemampuan keuangan daerah dalam penyelenggaraan urusan daerah. Artinya daerah harus memiliki kewenangan dan kemampuan untuk menggali sumber keuangan sendiri, mengelola dan menggunakannya dalam membiayai penyelenggaraan pemerintahan daerah. Pendapatan Asli Daerah (PAD) merupakan sumber 
keuangan utama yang didukung oleh kebijakan perimbangan keuangan pusat dan daerah sebagai konsekuensi logis tanggung jawab negara terhadap wilayahnya. Untuk mendukung otonomi daerah dikeluarkan UU No.25 Tahun 1999 tentang Perimbangan Keuangan Pusat dan Daerah sebagai tanggung jawab pemerintah terhadap daerah. Di samping PAD daerah juga mendapat dana perimbangan berupa dana alokasi umum (DAU) yang bersifat block grant, dana alokasi khusus (DAK) yang bersifat specific grant dan pinjaman daerah (Warsito, 1999). Dengan peraturan ini diharapkan daerah akan mampu memacu pembangunan daerah, sehingga kesenjangan pertumbuhan antar daerah secara perlahan dapat dikurangi. Nantinya pemerintah daerah tidak lagi akan bergantung kepada pemerintah pusat, melainkan secara mandiri dapat memprogramkan pembangunan daerahnya sesuai dengan kemampuan.

Pengertian pendapatan asli daerah menurut Undang-Undang No. 28 Tahun 2009 yaitu sumber keuangan daerah yang digali dari wilayah daerah yang bersangkutan yang terdiri dari hasil pajak daerah, hasil retribusi daerah, hasil pengelolaan kekayaan daerah yang dipisahkan dan lain-lain pendapatan asli daerah yang sah. Menurut Nurcholis (2007:182), pendapatan asli daerah adalah pendapatan yang diperopleh daerah dari penerimaan pajak daerah, retribusi daerah, laba perusahaan daerah, dan lain-lain yang sah. Dari beberapa pendapat di atas dapat disimpulkan bahwa pendapatan asli daerah adalah semua penerimaan keuangan suatu daerah, dimana penerimaan keuangan itu bersumber dari potensi-potensi yang ada di daerah tersebut misalnya pajak daerah, retribusi daerah dan lain-lain, serta penerimaan keuangan tersebut diatur oleh peraturan daerah. Kabupaten Paser merupakan wilayah Provinsi Kalimantan Timur yang terletak paling selatan, tepatnya pada posisi $0^{\circ} 48^{\prime} 29^{\prime \prime}-2^{0} 29^{\prime} 35^{\prime \prime}$ LS dan $115^{0} 32^{\prime} 14$ '$166^{0} 39^{\prime} 45^{\prime \prime}$ BT. Kabupaten Paser terletak pada ketinggian yang berkisar antara 0-500 meter di atas permukaan laut.

Tabel 1. Batas wilayah Kabupaten Paser

\begin{tabular}{|l|l|}
\hline \multicolumn{1}{|c|}{ Utara } & Kabupaten Kutai Barat dan Kutai Kartanegara \\
\hline$\underline{\text { Selatan }}$ & Kabupaten Kota Baru (Kalimantan Selatan) \\
\hline$\underline{\text { Barat }}$ & $\underline{\text { Kabupaten Tabalong (Kalimantan Selatan })}$ \\
\hline$\underline{\text { Timur }}$ & $\underline{\text { Selat Makassar }}$ \\
\hline
\end{tabular}

Sumber: Data penelitian diolah, 2015

Luas wilayah Kabupaten Paser 12.592,62 km², terdiri dari 10 kecamatan dengan 139 buah desa/kelurahan dan empat buah UPT (Unit Pemukiman Transmigrasi). Jumlah penduduk pada tahun 2012 mencapai 247.612 jiwa atau memiliki kepadatan penduduk 20 jiwa $/ \mathrm{km}^{2}$.

Dari segi konstelasi regional, Kabupaten Paser berada di sebelah Selatan Provinsi Kalimantan Timur. Posisinya dilintasi oleh jalan arteri primer (jalan negara/nasional) yang menghubungkan Provinsi Kalimantan Timur dengan Kalimantan Selatan. Pada bagian timur Kabupaten Paser melintang Selat Makassar, dimasa yang akan datang memiliki prospek dan fungsi penting sebagai jalur alternatif pelayaran internasional. Pelabuhan laut utama di Kabupaten Paser, yaitu Pelabuhan Teluk Adang terletak $12 \mathrm{~km}$ ke arah utara Ibukota Kabupaten (Kota Tanah Grogot), sedangkan Kota Tanah Grogot berjarak lebih kurang dari $145 \mathrm{~km}$ dari Balikpapan atau $260 \mathrm{~km}$ dari Ibukota Provinsi Kalimantan Timur, Kota Samarinda.

PDRB Kabupaten Paser Atas Dasar Harga Berlaku (ADHB) pada tahun 2012 sebesar 17,84 Triliyun rupiah dengan sektor potensialnya dari pertambangan non migas (batubara) dan merupakan penghasil PDRB per kapita terbesar ketiga di Provinsi Kalimantan Timur setelah Kabupaten Kutai Timur dan Kabupaten Kutai Kertanegara. Mengingat potensi ekonomi 
Kabupaten Paser yang cukup besar, maka dibutuhkan berbagai sarana dan prasarana pendukung kota diantaranya sarana akomodasi yang memiliki fasilitas memadai yang dapat digunakan untuk berbagai kegiatan baik pada skala lokal maupun regional. Atas dasar pertimbangan tersebut, Pemerintah Kabupaten Paser telah membangun Hotel Grand Sadurengas ("Hotel"), berikut sarana, prasarana/fasilitas pendukungnya. Namun mengingat Pemerintah Kabupaten Paser tidak memiliki SDM untuk mengelola hotel dimaksud, maka Pemerintah Kabupaten Paser berencana untuk menyerahkan pengelolaan Hotel Grand Sadurengas ini kepada pihak yang memiliki kompetensi di bidangnya yakni manajemen pengelola hotel (operator hotel). Dalam konteks tersebut di atas, Pemerintah Kabupaten Paser harus mempunyai acuan berupa penelitian yang akan dijadikan dasar untuk melakukan seleksi manajemen pengelola hotel (operator hotel) ini. Hasil penelitian ini juga diharapkan dapat memperkuat posisi tawar (bargaining position) Pemerintah Kabupaten Paser dengan pihak calon manajemen pengelola hotel (operator hotel) dimaksud.

\section{Metode}

\section{A. Jenis Penelitian}

Penelitian ini berbentuk analisis deskriptif, yaitu jenis penelitian survei yang bertujuan menjelaskan potensi pasar dan aspek keuangan yang bisa digunakan oleh perusahaan dalam merumuskan hasil penelitian nilai ekonomis pemanfaatan Hotel Grand Sadurengas.

Penelitian deskriptif mencoba mencari deskripsi yang tepat dan cukup dari semua aktivitas, objek, proses, dan manusia (Sulistyo-Basuki, 2010). Penelitian deskriptif mengenal berbagai bentuk yang dapat dikategorikan seperti survei, studi kasus, penelitian, kausal-komparatif, penelitian korelasi, dan sebagainya.

\section{B. Variabel Penelitian}

Variabel penelitian adalah sesuatu yang dijadikan obyek pengamatan penelitian. Variabel penelitian ini disusun atas dasar permasalahan dan tujuan penelitian, penelitian pustaka dan hasil penelitian sebelumnya. Variabel-variabel dalam penelitian ini akan diuraikan sebagaimana berikut:

1) Potensi pasar (Market potential)

Untuk mengetahui potensi pasar maka perlu diketahui seluruh permintaan atau kebutuhan konsumen yang didasarkan atas dua faktor: jumlah konsumen potensial dan daya beli. Konsumen potensial adalah konsumen yang memiliki keinginan untuk membeli sedangkan daya beli adalah kemampuan konsumen dalam rangka untuk membeli jasa sehingga diperlukan metode peramalan permintaan untuk mengetahui potensi pasar dari pendirian Hotel Grand Sadurengas di Kabupaten Paser. Untuk peramalan permintaan pasar Hotel Grand Sadurengas, penelitian akan menggunakan data jumlah permintaan jasa hotel di Kabupaten Paser.

2) Analisis pesaing

Dalam menghadapi lingkungan pesaing yang terus berubah di masa yang akan datang dalam kerangka berpikir untuk menyoroti masalah pesaing dan pengembangan strategi pemasaran maka dilakukan analisis competitive profile matrix (CPM) yang membandingkan antara perusahaan yang diteliti secara internal dan eksternal dengan pesaing yaitu hotel yang berada dekat dengan lokasi Hotel Grand Sadurengas di Kabupaten Paser.

3) Jenis strategi pemasaran

Pada intinya strategi mengandung pengertian tentang apa yang harus menjadi sasaran, di mana, siapa dan pada produk pasar disalah satu industri mana yang menjadi sasaran, bagaimana kegiatan dan penelitian ditempatkan untuk masing-masing produk pasar dan keuntungan optimal. 
Berdasarkan uraian di atas dilakukan penelitian untuk mengetahui sasaran dengan melakukan segmentasi pasar, targetting dan positioning. Didalam menentukan strategi yang tepat dari Hotel Grand Sadurengas digunakan teknik analisis SWOT (strengths, weaknesses, opportunities, threats) dengan membandingkan faktor-faktor internal perusahaan (internalfactors analysis summary/IFAS) dengan faktor-faktor eksternal perusahaan (internal factors analysis summary/EFAS) sehingga menghasilkan 4 strategi yaitu strategi strenghts- oppotunities/SO, strategi weaknesses-opportunities/WO, strategi strengths- threats/ST dan strategi weaknesses-threats/WT.

Pernyataan-pernyataan tentang strategi di atas secara eksplisit merupakan kunci keberhasilan Hotel Grand Sadurengas dalam menghadapi perubahan lingkungan bisnis. Penelitian ini menyadari pentingnya strategi pemasaran untuk memberikan kesatuan arah bagi semua anggota organisasi, karena bila konsep strategi pemasaran tidak jelas, maka keputusan dari aspek pasar akan kurang jelas pula.

4) Pangsa pasar (Market share)

Market share adalah luas pasar yang dikuasai pesaing Hotel Grand Sadurengas dibandingkan dengan luas pasar sasaran secara total atau pasar industri yang ada, atau sebaliknya yaitu luas pasar yang sekiranya telah dikuasai dan diharapkan akan dikuasai oleh Hotel Grand Sadurengas.

5) Initial Cash Flow

Sejumlah dana-dana yang digunakan untuk investasi pendirian perusahaan.

6) Operational Cash Flow

Jumlah dana yang dibutuhkan untuk membangun Hotel Grand Sadurengas. Penerimaan kas yang dihasilkan oleh operasi bisnis dalam periode waktu tertentu, diperoleh dengan menambahkan laba bersih dengan depresiasi serta bunga sesudah pajak, sehingga diperoleh arus kas (sesudah pajak).

7) Operational Cash Flow

Sejumlah dana yang tersisa dari aktiva tetap (tanah dan bangunan) dan modalkerja.

\section{Prosedur Pengumpulan Data}

1) Observasi

Yaitu pengumpulan data dengan mengadakan observasi secara langsung terhadap kegiatan yang dilakukan oleh Hotel Grand Sadurengas terutama dalam hal letak hotel, bentuk hotel dan sarana dan prasarananya, serta potensi pasarnya.

2) Wawancara/Interview

1. Wawancara langsung dengan pemilik usaha dari Hotel Grand Sadurengas, yang dalam hal ini adalah Pemerintah Kabupaten Paser, dan juga wawancara dengan pengelola sementara.

2. Wawancara dengan hotel pesaing terdekat

3. Wawancara dengan biro perjalanan terdekat

3) Dokumentasi

Kebutuhan data dalam hal ini adalah:

1. Dana yang dibutuhkan dalam investasi pendirian Hotel Grand Sadurengas, dari awal hingga siap untuk di pasarkan.

2. Dana dari pinjaman bank serta bunganya (kalau hotel tersebut dibangun sebagian atau seluruhnya berasal dari bank).

3. Laporan keuangan hotel

4. Laporan pajak

5. Jumlah kamar serta kelasnya Hotel Grand Sadurengas 
6. Jumlah Tenaga kerja serta bagiannya dan gajinya di Hotel Grand Sadurengas.

7. Harga jual/kamar di Hotel Grand Sadurengas

8. Jumlah hotel dan kelasnya serta harganya yang ada di Kabupaten paser dari Dinas Pariwisata (minimal 5 tahun terakhir).

9. Tingkat hunian hotel di Kabupaten Paser dari Dinas Pariwisata (minimal 5 tahun terakhir).

10.Jumlah wisatawan di Kabupaten Paser dari Dinas Pariwisata (minimal 5 tahun terakhir).

\section{Metode Analisis Data}

\section{Analisis Aspek Pasar}

Langkah-langkah analisis aspek pasar yang dilakukan adalah:

a) Mengestimasikan jumlah wisatawan sebagai demand dan jumlah biro perjalanan wisata sebagai supply, data ini diperoleh dari Dinas Pariwisata Kabupaten Paser. Perhitungan dilakukan dengan menggunakan metode Trend Linear.

b) Menganalisis persaingan dengan menggunakan analisis competitive profilematrix (CPM) dalam menghadapi lingkungan pesaing yang terus berubah di masa yang akan datang dalam kerangka berpikir untuk menyoroti masalah pesaing dan pengembangan pasar adalah salah satu jalan terbaik bagi manajemen Hotel Grand Sadurengas. Analisis persaingan ini dilakukan dengan cara observasi dan wawancara terhadap pesaing hotel yang telah ada sebelumnya dan sebuah Biro perjalanan wisata yang berlokasi dekat dengan lokasi dari Hotel Grand Sadurengas.

c) Menciptakan strategi pemasaran yang terbaik untuk perusahaan dengan menggunakan segmentasi pasar, targeting dan positioning (STP) yang kemudian diikuti dengan menentukan internal factors analysis summary (IFAS) yaitu kekuatan dan kelemahan perusahaan dan external factors analysis summary (EFAS) yaitu peluang dan ancaman yang kemudian dilakukan analisis SWOT (strengths, weaknesses, opportunities, threats) sehingga menghasilkan 4 (empat) strategi yaitu strategi SO, strategi WO, strategi ST dan strategi WT.

d) Mengestimasi bagian pasar (market share) yang dapat diraih melalui data yang diperoleh dengan membandingkan estimasi penjualan dari Hotel Grand Sadurengas dengan total perkiraan penjualan jasa hotel di Kabupaten Paser

\section{Analisis Aspek Keuangan}

Langkah-langkah analisis aspek keuangan antara lain:

a) Menelaah dana investasi awal (initial investment)

angkah yang dilakukan adalah dengan melihat jumlah aktiva tetap, biaya pra operasi dan modal kerja.

b) Pendapatan dan biaya penjualan

Langkah yang dilakukan adalah dengan membuat proyeksi pendapatan dan biaya penjualan

c) Menentukan proyeksi operational cash flow

Langkah yang dilakukan adalah dari laporan rugi laba yang diperoleh dengan menambahkan laba bersih dengan depresiasi serta bunga sesudah pajak, sehingga diperoleh arus kas (sesudah pajak).

d) Menentukan Termin al Cash Flow

Untuk menentukan Terminal Cash Flow maka perlu diketahui cash flow nilai sisa (residu) dari proyek yang memiliki nilai sisa meskipun aktiva-aktiva tetapnya sudah memiliki nilai ekonomis lagi seperti tanah, bangunan dan modal kerja.

e) Menentukan biaya modal rata-rata tertimbang (WACC) 
Cara yang dipergunakan antara lain:

(1) Menaksir aliran kas dengan memisahkan aliran kas yang terjadi karena keputusan investasi dan aliran kas yang terjadi karena keputusan pembelanjaan, maka formula yang dipergunakan adalah: Laba setelah pajak + penyusutan + bunga (1- tarif pajak).

(2) Menghitung biaya modal rata-rata tertimbang dengan menggunakan dasar setelah pajak. Biaya modal merupakan perkalian antara besarnya biaya modal dari masing-masing sumber pembelanjaan dengan proporsi dana yang digunakan.

f) Perhitungan NPV, IRR dan Payback Period

(1) Payback period

Metode ini mencoba mengukur seberapa cepat suatu investasi bisa kembali. Karena itu satuan hasilnya bukan persentase, tetapi satuan waktu seperti tahun, bulan. Apabila periode payback ini lebih pendek daripada yang diisyaratkan, maka proyek dikatakan menguntungkan, sedangkan kalau lebih lama proyek ditolak dan dasar yang dipergunakan adalah aliran kas, bukan laba (Husnan dan Suwarsono, 2000).

Menghitung dengan model Net Present Value (NPV) dengan rumus sebagaiberikut:

$$
\begin{array}{ll}
\mathrm{NPV}= & \frac{\mathrm{CFO}_{1}}{(1+\mathrm{r})^{1}}+\frac{\mathrm{CFo}_{2}}{(1+\mathrm{r})^{2}}+\frac{\mathrm{CFO}_{3}}{(1+\mathrm{r})^{3}}+\ldots \ldots+\frac{\mathrm{CFo}_{\mathrm{n}}+\mathrm{TCF}}{(1+\mathrm{r})^{\mathrm{n}}}-10 \\
\mathrm{NPV} & =\text { Net Present Value } \\
\mathrm{CFo} & =\text { Cash Flow Operational dari tahun ke } 1 \text { sampai tahun ke } 5 \\
\mathrm{n} & =5 \text { tahun. } \\
\mathrm{I} & =\text { Jumlah investasi yang telah tertanam dalam proyek } \\
\mathrm{r} & =\text { Tingkat bunga yang relevan (cost of capital) } \\
\mathrm{TCF} & =\text { Terminal Cash Flow }
\end{array}
$$

Dengan tahapan antara lain: Menentukan nilai sekarang dari arus kas, termasuk arus masuk dan arus keluar, yang didiskontokan pada biaya modal proyek kemudian menjumlahkan arus kas yang didiskontokan sehingga hasilnya didefinisikan sebagai NPV proyek, jika NPV positif, maka proyek harus diterima sedangkan jika NPV negative, maka proyek harus ditolak.

Menghitung dengan model IRR dengan rumus:

$$
A 0=\frac{A_{1}}{(1+r)^{1}}+\frac{A_{2}}{(1+y)^{2}}+\frac{A_{3}}{(1+r)^{3}}+\ldots \ldots .+\frac{A_{n}}{(1+r)^{n}}-10
$$

di mana:

$$
\begin{array}{ll}
\text { Ao } & \text { Jumlah aliran kas awal } \\
\text { A 1-A 10 } & =\text { Jumlah aliran kas masuk bersih } \\
\text { r } & \text { Internal Rate of Return }
\end{array}
$$

Jika $r$ lebih tinggi dari cost of capital (biaya modal) maka rencana pengembangan investasi dapat diterima dan jika lebih rendah maka investasi dikatakan tidak layak. Untuk menentukan risiko investasi dengan analisis sensitivitas akan dicari dengan membandingkan ketiga kondisi yaitu pesimis, moderat dan optimis terhadap market size, market share, harga jual per unit, biaya variabel perunit dan biaya tetap, yang bertujuan untuk mengetahui variabel apa yang paling sensitif terhadap keberhasilan pendirian Hotel Grand Sadurengas, jarak antara kategori optimis dan 
pesimis yanglebih kecil merupakan investasi berisiko rendah (Husnan \& Suwarsono, 2001).

Kemudian sebagai tambahan analisis digunakan pula analisis Cost-Volume-Profit (CVP) dengan tujuan untuk mengetahui penjualan minimal dan sebagai alat perencanaan laba.

\section{Penentuan Bagi Hasil Pengelolaan Hotel Grand Sadurengas}

Setelah analisis aspek pasar dan aspek keuangan dari Hotel Grand Sadurengas telah dilakukan, maka selanjutnya adalah melakukan bargaining position dengan pihak calon pengelola hotel. Pada penelitian ini penentuan/pendistribusian bagi hasil difokuskan pada metode Profit Sharing. Dalam metode tersebut pemodal (Pemerintah Kabupaten Paser) dengan Pengelola (Operator Hotel) menentukan persentasi (nisbah) Profit Sharing. Untuk penentuan persentase (nisbah) bagi hasil dengan metode profit sharing tidak ada ukuran yang pasti. Itu semua tergantung kesepakatan antara kedua belah pihak. Namun pada umumnya adalah 60:40 (mengacu pada bank syariah). Artinya setelah keuntungan bersih perusahaan ditentukan, maka bagian keuntungan untuk pemodal (Pemerintah Kabupaten Paser) sebesar 60\% dari keuntungan bersih, sedangkan sisanya $(40 \%)$ merupakan bagian keuntungan untuk pengelola (operator hotel). Selanjutnya, setelah ada kesepakatan tentang teknis bagi hasil, maka semua kesepatakan yang ada dibuatkan naskah kerjasamanya di depan notaris. Perlu diketahui bahwa untuk meminimalisasi risiko bagi Investor selaku pemilik modal, umumnya dalam perjanjian Kerjasama Bagi hasil, disisipkan klausul yang menyatakan Pengelola selalu memberikan laporan kerja dan laporan keuangan kepada pemilik modal secara rutin. Sehingga, pemodal dapat mengetahui perkembangan usahanya

\section{HASIL DAN PEMBAHASAN}

\section{A. Estimasi Jumlah Wisatawan}

Yang dimaksud dengan jumlah wisatawan disini adalah jumlah wisatawan yang menginap di hotel yang ada di Kabupaten Paser. Berdasarkan data Kabupaten Paser Dalam Angka 2013, jumlah tamu yang menginap di Hotel yang ada di Kabupaten Paser adalah seperti yang nampak pada tabel berikut.

Tabel 2. Rata-Rata Lama Menginap Tamu

\begin{tabular}{|c|c|}
\hline Bulan & Tamu (orang) \\
\hline Januari & 4.125 \\
\hline Februari & 4.081 \\
\hline Maret & 4.200 \\
\hline April & 4.128 \\
\hline Mei & 4.087 \\
\hline Juni & 3.934 \\
\hline Juli & 4.098 \\
\hline Agustus & 3.755 \\
\hline September & 3.962 \\
\hline Oktober & 4.172 \\
\hline Nopember & 4.389 \\
\hline Desember & 4.389 \\
\hline
\end{tabular}

Sumber: Data penelitian diolah, 2015 
Berdasarkan data yang ada tersebut, selanjutnya diestimasi jumlah wisatawan yang menginap di hotel yang ada di Kabupaten Paser selama 6 (enam) tahun ke depan, yaitu 2013-2018. Estimasi dan uji model menggunakan Statistical Package for the Social Sciences (SPSS) versi 17. Sebelum melakukan estimasi maka ditentukan dulu model yang lebih baik dalam menjelaskan kecenderungan data. Hasilnya seperti berikut.

Tabel 3 Penentuan Model Estimasi

\begin{tabular}{|c|c|c|c|c|c|c|c|}
\hline \multirow{2}{*}{$\begin{array}{c}\text { Equatio } \\
\mathbf{n}\end{array}$} & \multicolumn{3}{|c|}{ Model Summary } & \multicolumn{3}{c|}{ Parameter Estimates } \\
\cline { 2 - 8 } & $\begin{array}{c}\text { Squar } \\
\mathbf{e}\end{array}$ & Df & F & Sigf & b0 & b1 & b2 \\
& & & & & & \\
\hline Linear & .073 & 10 & .79 & .395 & 4023.23 & 13.3497 & - \\
\hline Quadratic & .501 & 9 & 4.52 & .044 & 4343.86 & -124.07 & 10.5704 \\
\hline
\end{tabular}

Sumber: Data diolah, 2015

Dari tabel di atas dapat dirumuskan:

Model linear: $\quad \mathrm{Yt}=4.023,23+13,3497 \mathrm{~T}$

Model Kuadratik: $\mathrm{Yt}=4.343,86-124,07 \mathrm{~T}+10,5704 \mathrm{~T}^{2}$

$\mathrm{R}$ Square mengukur kekuatan hubungan antara nilai variabel dependent sebenarnya (observed) dan nilai variabel dependent yang diprediksi model (fit). Dari nilai R square ini, terlihat bahwa model kuadratik adalah model yang lebih baik dalam menjelaskan kecenderungan data. Output kurva fit selanjutnya secara visual memberikan penilaian nilai fit masing-masing model terhadap nilai observed-nya.

\section{Gambar 1. Curvefit Untuk Tingkat Hunian Hotel di Kabupaten Paser}

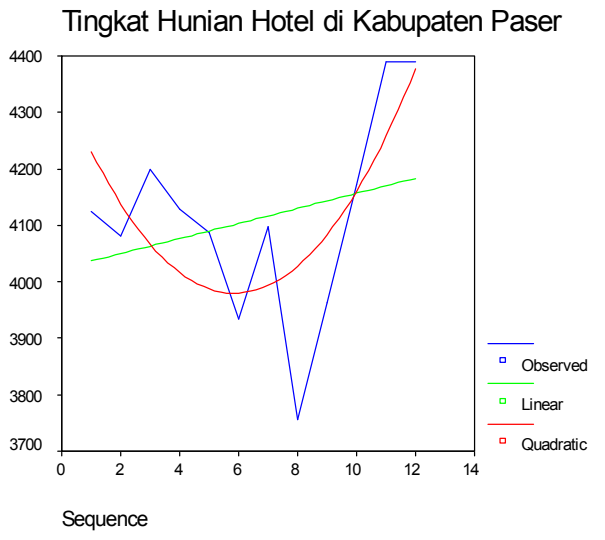

Sumber: Data diolah, 2015

Dari plot ini, terlihat bahwa model kuadratik lebih baik mendekati kecenderungan data dibandingkan model linear.

Selain membandingkan antara nilai fit dan nilai observednya, untuk pemeriksaan secara visual lebih lanjut, dapat melihat plot dari residual dibandingkan dengan nilai fit. Nilai residual adalah selisih antara nilai observed dengan nilai fit. 
Gambar 2. Plot Residual dan Fit Untuk Model Linear

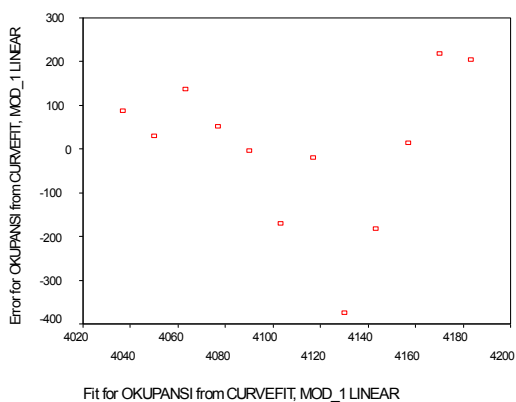

Sumber: Data diolah, 2015

Sedangkan plot residual dan fit untuk model kuadratik adalah sebagai berikut.

Gambar 3. Plot Residual dan Fit Untuk Model Kuadratik

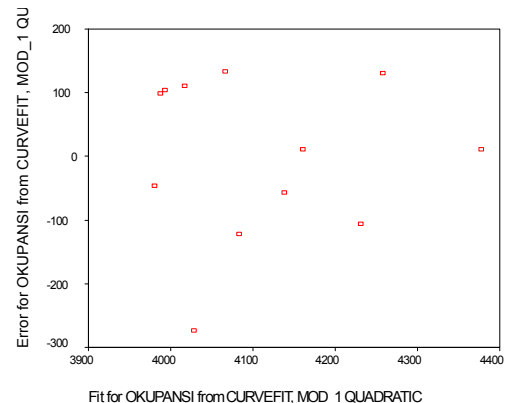

Sumber: Data diolah, 2015

Model yang memenuhi syarat untuk peramalan adalah model dimana residualnya bebas terhadap nilai fit. Dari kedua Plot Residual Dan Fit, dalam model linear terlihat adanya pola titik-titik yang menyebar secara linear, tetapi pada model kuadratik, titik-titik relatif menyebar secara tidak beraturan. Karenanya, dapat disimpulkan bahwa selain nilai $\mathrm{R}$ square yang lebih baik, model kuadratik ternyata lebih memenuhi syarat dibandingkan model linear, sehingga model kuadratik lebih tepat digunakan untuk peramalan data.

Setelah menetapkan model kuadratik sebagai model terbaik, tahap selanjutnya adalah melakukan forecasting dengan model tersebut. Berdasarkan hasil perhitungan olah statistik (SPSS) diketahui estimasi jumlah wisatawan yang akan menginap di hotel di Kabupaten Paser adalah seperti berikut.

Tabel 4. Estimasi Wisatawan Yang Menginap di Hotel Kabupaten Paser

\begin{tabular}{|c|c|c|c|c|c|c|c|c|c|}
\hline $\begin{array}{l}\text { Bulan } \\
\text { (2014) }\end{array}$ & Yt & $\begin{array}{l}\text { Bulan } \\
\text { (2015) }\end{array}$ & Yt & $\begin{array}{l}\text { Bulan } \\
(2016)\end{array}$ & Yt & $\begin{array}{l}\text { Bulan } \\
\text { (2017) }\end{array}$ & $Y t$ & $\begin{array}{l}\text { Bulan } \\
\text { (2018) }\end{array}$ & Yt \\
\hline Januari & 7.849 & Januari & 14.224 & Januari & 23.644 & Januari & 36.108 & Januari & 51.617 \\
\hline Pebruari & 8.264 & Pebruari & 14.893 & Pebruari & 24.567 & Pebruari & 37.285 & Pebruari & 53.047 \\
\hline Maret & 8.700 & Maret & 15.583 & Maret & 25.510 & Maret & 38.482 & Maret & 54.498 \\
\hline April & 9.157 & April & 16.294 & April & 26.475 & April & 39.700 & April & 55.970 \\
\hline Mei & 9.636 & Mei & 17.026 & Mei & 27.461 & Mei & 40.940 & Mei & 57.463 \\
\hline Juni & $\begin{array}{r}10.13 \\
5 \\
\end{array}$ & Juni & 17.779 & Juni & 28.468 & Juni & 42.200 & Juni & 58.977 \\
\hline Juli & $\begin{array}{r}10.65 \\
6 \\
\end{array}$ & Juli & 18.554 & Juli & 29.496 & Juli & 43.482 & Juli & 60.513 \\
\hline Agustus & $\begin{array}{r}11.19 \\
8 \\
\end{array}$ & Agustus & 19.349 & Agustus & 30.545 & Agustus & 44.785 & Agustus & 62.069 \\
\hline
\end{tabular}




\begin{tabular}{|c|r|l|l|l|l|l|l|l|l|}
\hline September & $\begin{array}{r}11.76 \\
1\end{array}$ & September & 20.166 & $\begin{array}{c}\text { Septembe } \\
\mathrm{r}\end{array}$ & 31.615 & September & 46.109 & $\begin{array}{c}\text { Septembe } \\
\mathrm{r}\end{array}$ & 63.647 \\
\hline Oktober & $\begin{array}{r}12.34 \\
5\end{array}$ & Oktober & 21.004 & Oktober & 32.707 & Oktober & 47.454 & Oktober & 65.246 \\
\hline Nopember & $\begin{array}{r}12.95 \\
0\end{array}$ & Nopember & 21.863 & Nopember & 33.820 & Nopember & 48.821 & Nopember & 66.866 \\
\hline Desember & $\begin{array}{r}13.57 \\
7\end{array}$ & Desember & 22.743 & Desember & 34.953 & Desember & 50.208 & Desember & 68.507 \\
\hline
\end{tabular}

Sumber: Data diolah, 2015

Selanjutnya akan di estimasi jumlah hunian kamar hotel di Kabupaten Paser dengan cara yang sama seperti analisis estimasi wisatawan.

Berdasarkan data Kabupaten Paser Dalam Angka 2013, jumlah hunian kamar hotel yang ada di Kabupaten Paser adalah seperti yang nampak pada tabel berikut.

Tabel 5. Tingkat Hunian Hotel Dirinci Per Bulan

di Kabupaten Paser

\begin{tabular}{|c|c|}
\hline Bulan & Hunian Kamar \\
\hline Januari & 3.372 \\
\hline Februari & 2.556 \\
\hline Maret & 3.472 \\
\hline April & 3.297 \\
\hline Mei & 3.365 \\
\hline Juni & 3.303 \\
\hline Juli & 3.476 \\
\hline Agustus & 3.281 \\
\hline September & 3.450 \\
\hline Oktober & 3.446 \\
\hline Nopember & 3.232 \\
\hline Desember & 3.437 \\
\hline
\end{tabular}

Sumber: Data penelitian diolah, 2015

Berdasarkan data yang ada tersebut, selanjutnya diestimasi tingkat hunian kamar hotel yang ada di Kabupaten Paser selama 6 (enam) tahun ke depan, yaitu 2013-2018. Estimasi dan uji model menggunakan Statistical Package for the Social Sciences (SPSS) versi 17. Sebelum melakukan estimasi maka ditentukan dulu model yang lebih baik dalam menjelaskan kecenderungan data. Hasilnya seperti berikut.

Tabel 6. Penentuan Model Estimasi

\begin{tabular}{|l|l|l|l|l|l|l|c|}
\hline \multirow{2}{*}{ Equation } & \multicolumn{3}{|c|}{ Model Summary } & \multicolumn{2}{c|}{ Parameter Estimates } \\
\cline { 2 - 8 } & $\begin{array}{c}\text { R } \\
\text { Square }\end{array}$ & Df & F & Sigf & b0 & b1 & b2 \\
\hline Linear & .635 & 10 & 10.56 & .040 & 3141.27 & 25.5350 & - \\
\hline Quadratic & .177 & 9 & 4.52 & .417 & 3000.48 & 85.8759 & - \\
\hline
\end{tabular}

Sumber: Data diolah, 2015 
Dari tabel di atas dapat dirumuskan:

Model linear: $\quad \mathrm{Yt}=3.141,27+25,5350 \mathrm{~T}$

Model Kuadratik: $\mathrm{Yt}=3.000,48+85,8759 \mathrm{~T}-4,6416 \mathrm{~T}^{2}$

Dari nilai $\mathrm{R}$ square, terlihat bahwa model linear adalah model yang lebih baik dalam menjelaskan kecenderungan data.

Output kurva fit selanjutnya secara visual memberikan penilaian nilai fit masing-masing model terhadap nilai observed-nya.

Gambar 4.

Curvefit Untuk Tingkat Hunian Kamar

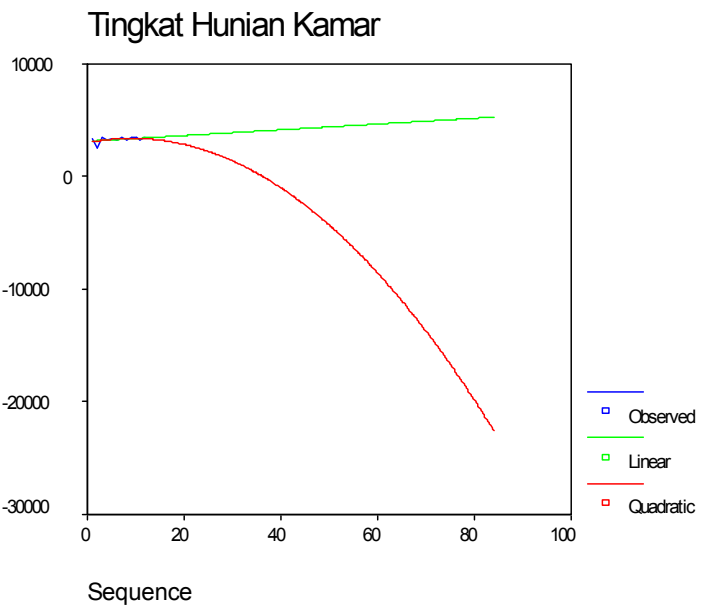

Sumber: Data diolah, 2015

Dari plot ini, terlihat bahwa model linear lebih baik mendekati kecenderungan data dibandingkan model kuadratik. Selain membandingkan antara nilai fit dan nilai observednya, untuk pemeriksaan secara visual lebih lanjut, dapat melihat plot dari residual dibandingkan dengan nilai fit. Nilai residual adalah selisih antara nilai observed dengan nilai fit.

Gambar 5.

Plot Residual Dan Fit Untuk Model Linear

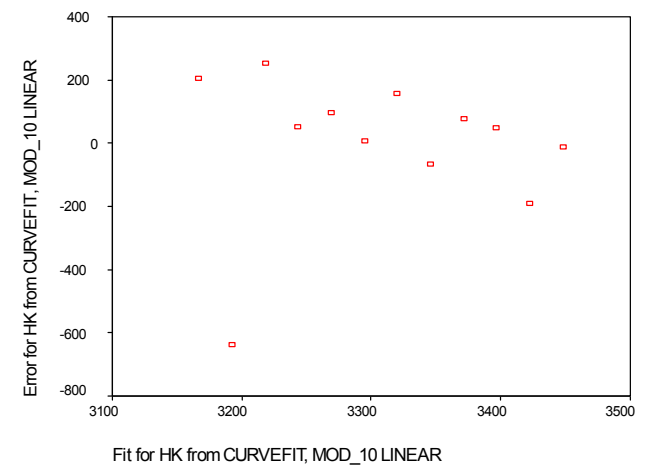

Sumber: Data diolah, 2015 
Gambar 6

Plot Residual Dan Fit Untuk Model Kuadratik

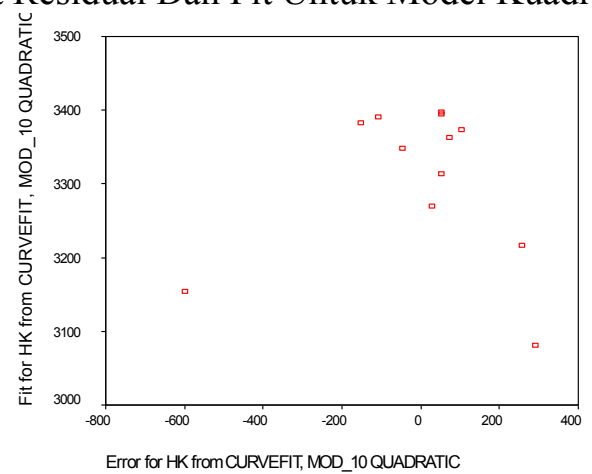

Sumber: Data diolah, 2015

Model yang memenuhi syarat untuk peramalan adalah model dimana residualnya bebas terhadap nilai fit. Dari kedua Plot Residual Dan Fit, dalam model linear terlihat tidak adanya pola titik-titik yang menyebar secara linear, tetapi pada model kuadratik, titik-titik relatif menyebar secara beraturan. Karenanya, dapat disimpulkan bahwa selain nilai $\mathrm{R}$ square yang lebih baik, model linear ternyata lebih memenuhi syarat dibandingkan model kuadratik, sehingga model linear lebih tepat digunakan untuk peramalan data.

Setelah menetapkan model linear sebagai model terbaik, tahap selanjutnya adalah melakukan forecasting dengan model tersebut. Berdasarkan hasil perhitungan olah statistik (SPSS) diketahui estimasi tingkat hunian kamar hotel di Kabupaten Paser adalah seperti berikut.

Tabel 7. Estimasi Tingkat Hunian Kamar Hotel Kabupaten Paser

\begin{tabular}{|l|c|l|c|l|c|l|l|l|l|}
\hline $\begin{array}{c}\text { Bulan } \\
\mathbf{( 2 0 1 4 )}\end{array}$ & Yt & $\begin{array}{c}\text { Bulan } \\
\mathbf{( 2 0 1 5 )}\end{array}$ & Yt & $\begin{array}{c}\text { Bulan } \\
\mathbf{( 2 0 1 6 )}\end{array}$ & Yt & $\begin{array}{c}\text { Bulan } \\
\mathbf{( 2 0 1 7 )}\end{array}$ & Yt & $\begin{array}{c}\text { Bulan } \\
\text { (2018) }\end{array}$ & \multicolumn{1}{|c|}{ Yt } \\
\hline Januari & 3.780 & Januari & 4.086 & Januari & 4.392 & Januari & 4.699 & Januari & 5.005 \\
\hline Pebruari & 3.805 & Pebruari & 4.112 & Pebruari & 4.418 & Pebruari & 4.724 & Pebruari & 5.031 \\
\hline Maret & 3.831 & Maret & 4.137 & Maret & 4.444 & Maret & 4.750 & Maret & 5.056 \\
\hline April & 3.856 & April & 4.163 & April & 4.469 & April & 4.776 & April & 5.082 \\
\hline Mei & 3.882 & Mei & 4.188 & Mei & 4.495 & Mei & 4.801 & Mei & 5.107 \\
\hline Juni & 3.907 & Juni & 4.214 & Juni & 4.520 & Juni & 4.827 & Juni & 5.133 \\
\hline Juli & 3.933 & Juli & 4.239 & Juli & 4.546 & Juli & 4.852 & Juli & 5.159 \\
\hline Agustus & 3.958 & Agustus & 4.265 & Agustus & 4.571 & Agustus & 4.878 & Agustus & 5.184 \\
\hline September & 3.984 & September & 4.290 & September & 4.597 & September & 4.903 & September & 5.210 \\
\hline Oktober & 4.009 & Oktober & 4.316 & Oktober & 4.622 & Oktober & 4.929 & Oktober & 5.235 \\
\hline Nopember & 4.035 & Nopember & 4.341 & Nopember & 4.648 & Nopember & 4.954 & Nopember & 5.261 \\
\hline Desember & 4.061 & Desember & 4.367 & Desember & 4.673 & Desember & 4.980 & Desember & 5.286 \\
\hline
\end{tabular}

Sumber: Data diolah, 2015 


\section{B. Analisis Competitive Profile Matrix (CPM)}

CPM mengidentifikasikan kompetitor utama perusahaan dan khususnya ancaman dan peluang dalam hubungan dengan posisi stratejik perusahaan. Lima kompetitor yang akan dibahas adalah Hotel Lorus, Hotel Indah, Tiara Hotel, Hotel Bumi Paser dan Hotel Mariola.

Tabel 8. Competitive Profile Matrix (CPM)

\begin{tabular}{|c|c|c|c|c|c|c|c|c|c|c|c|}
\hline Critical Success Factors & \multirow[t]{2}{*}{$\begin{array}{l}\text { Wei } \\
\text { ght }\end{array}$} & \multicolumn{2}{|c|}{$\begin{array}{l}\text { Hotel } \\
\text { Lorus }\end{array}$} & \multicolumn{2}{|c|}{$\begin{array}{l}\text { Hotel } \\
\text { Indah }\end{array}$} & \multicolumn{2}{|c|}{ Tiara Hotel } & \multicolumn{2}{|c|}{$\begin{array}{l}\text { Hotel Bumi } \\
\text { Paser }\end{array}$} & \multicolumn{2}{|c|}{$\begin{array}{c}\text { Hotel } \\
\text { Mariola }\end{array}$} \\
\hline & & Rtg & Scr & Rtg & Scr & Rtg & Scr & Rtg & Scr & Rtg & Scr \\
\hline $\begin{array}{l}\text { Tingkat pertumbuhan hotel } \\
\text { meningkat }\end{array}$ & 0,09 & 1 & 0,09 & 3 & 0,27 & 4 & 0,36 & 5 & $\begin{array}{c}0,4 \\
5\end{array}$ & 4 & 0,36 \\
\hline $\begin{array}{c}\text { Tingkat hunian kamar } \\
\text { meningkat }\end{array}$ & 0,10 & 2 & 0,2 & 3 & 0,3 & 4 & 0,4 & 4 & 0,4 & 5 & 0,5 \\
\hline $\begin{array}{c}\text { Tingkat wisatawan } \\
\text { meningkat }\end{array}$ & 0,09 & 4 & 0,36 & 3 & 0,27 & 3 & 0,27 & 2 & $\begin{array}{c}0,1 \\
8\end{array}$ & 5 & 0,45 \\
\hline $\begin{array}{l}\text { Transportasi di Kab. Paser } \\
\text { Lancar }\end{array}$ & 0,10 & 4 & 0,4 & 2 & 0,2 & 4 & 0,4 & 3 & 0,3 & 5 & 0,5 \\
\hline $\begin{array}{l}\text { Tempat wisata di kab. Paser } \\
\text { banyak }\end{array}$ & 0,08 & 4 & 0,32 & 4 & 0,32 & 2 & 0,16 & 1 & $\begin{array}{c}0,0 \\
8\end{array}$ & 5 & 0,4 \\
\hline $\begin{array}{l}\text { Stabilitas keamanan di kab. } \\
\text { Paser kondusif }\end{array}$ & 0,10 & 4 & 0,4 & 3 & 0,3 & 3 & 0,3 & 4 & 0,4 & 4 & 0,4 \\
\hline $\begin{array}{l}\text { Kebijakan pemerintah } \\
\text { daerah fleksibel }\end{array}$ & 0,08 & 3 & 0,24 & 3 & 0,24 & 3 & 0,24 & 2 & $\begin{array}{c}0,1 \\
6\end{array}$ & 4 & 0,32 \\
\hline $\begin{array}{l}\text { Budaya masyarakat di } \\
\text { lingkungan hotel } \\
\text { memberikan kenyamanan }\end{array}$ & 0,10 & 4 & 0,4 & 3 & 0,3 & 4 & 0,4 & 5 & 0,5 & 3 & 0,3 \\
\hline $\begin{array}{c}\text { Pelestarian terhadap } \\
\text { sumber daya alam di lingk. } \\
\text { Sekitar hotel }\end{array}$ & 0,10 & 4 & 0,4 & 3 & 0,3 & 4 & 0,4 & 4 & 0,4 & 3 & 0,3 \\
\hline $\begin{array}{l}\text { Hotel bekerja sama dengan } \\
\text { biro perjalanan }\end{array}$ & 0,08 & 4 & 0,32 & 3 & 0,24 & 4 & 0,32 & 1 & $\begin{array}{c}0,0 \\
8\end{array}$ & 3 & 0,24 \\
\hline $\begin{array}{l}\text { Hotel dapat dipesan melalui } \\
\text { agen-agen perjalanan }\end{array}$ & 0,10 & 3 & 0,3 & 4 & 0,4 & 4 & 0,4 & 2 & 0,2 & 5 & 0,5 \\
\hline Total & 1 & & 3,43 & & 3,14 & & 3,65 & & $\begin{array}{c}3,1 \\
5\end{array}$ & & 4,27 \\
\hline
\end{tabular}

Sumber: Data diolah, 2015

Keterangan:

$$
\begin{array}{cl}
1,00-1,80 & : \text { Ancaman besar } \\
1,81-2,60 & : \text { Ancaman kecil } \\
2,61-3,40 & : \text { Ancaman sedang } \\
3,41-4,20 & : \text { Peluang kecil } \\
4,21-5,00 & : \text { Peluang besar }
\end{array}
$$

Dari total score masing-masing pesaing pada tabel di atas, bahwa yang menjadi ancaman sedang bagi Hotel Grand Sadurengas adalah Hotel Indah dan Hotel Bumi Paser, karena total score berada pada rentang 2,61-3,40. Sedangkan untuk Hotel Lorus dan Tiara Hotel akan menciptakan peluang kecil bagi Hotel Grand Sadurengas, karena total score berada pada rentang 3,41-4,20. Selanjutnya Hotel Mariola akan menjadi peluang besar bagi Hotel Grand Sadurengas, karena total score berada pada rentang 4,21-5,00. 


\section{Analisis SWOT}

Analisis Lingkungan Eksternal

Analisis ini dilaksanakan pada suatu kondisi dan situasi sekarang yang dihadapi oleh Hotel Grand Sadurengas dalam melakukan aktivitas utamanya.

Tabel 9. External Factors Analysis Summary (EFAS)

\begin{tabular}{|l|c|c|c|}
\hline \multicolumn{1}{|c|}{ Indikator Variabel Eksternal } & Bobot & Rating & Score \\
\hline 1. Tingkat pertumbuhan hotel meningkat & 0,05 & 2 & 0,11 \\
\hline 2. Tingkat hunian kamar meningkat & 0,10 & 3,5 & 0,34 \\
\hline 3. Tingkat wisatawan meningkat & 0,10 & 3,5 & 0,34 \\
\hline 4. Transportasi di Kab. Paser Lancar & 0,08 & 3 & 0,25 \\
\hline 5. Tempat wisata di Kab. Paser banyak & 0,11 & 4 & 0,44 \\
\hline $\begin{array}{l}\text { 6. Stabilitas keamanan di kab. Paser } \\
\text { kondusif }\end{array}$ & 0,10 & 3,5 & 0,34 \\
\hline $\begin{array}{l}\text { 7. Kebijakan pemerintah daerah fleksibel } \\
\text { 8. Budaya masyarakat di lingkungan hotel } \\
\text { memberikan kenyamanan }\end{array}$ & 0,08 & 3 & 0,25 \\
\hline $\begin{array}{l}\text { 9. Pelestarian terhadap sumber daya alam di } \\
\text { lingk. Sekitar hotel }\end{array}$ & 0,10 & 3,5 & 0,34 \\
\hline $\begin{array}{l}\text { 10.Hotel bekerja sama dengan biro } \\
\text { perjalanan }\end{array}$ & 0,10 & 3,5 & 0,34 \\
\hline $\begin{array}{l}\text { 11.Hotel dapat dipesan melalui agen-agen } \\
\text { perjalanan }\end{array}$ & 0,10 & 3,5 & 0,34 \\
\hline \multicolumn{1}{|c|}{ Total } & $\mathbf{1 , 0 0}$ & & $\mathbf{3 , 3 9}$ \\
\hline
\end{tabular}

Sumber: Data diolah, 2015

Berdasarkan hasil analisis lingkungan eksternal seperti yang disajikan pada tabel di atas dapat diketahui bahwa hasil perkalian bobot dan rating didapatkan hasil keseluruhan jumlah nilai terbobot total sebesar 3,39 untuk EFAS Matriks. Hal ini menunjukkan bahwa Hotel Grand Sadurengas berada pada posisi yang baik untuk lebih mengembangkan perusahaan, tetapi tidak menutup kemungkinan untuk tetap waspada terhadap ancamanancaman yang ada. Setelah melakukan analisis terhadap lingkungan strategis eksternal, maka selanjutnya akan dilakukan analisis terhadap lingkungan internal yang dihadapi Hotel Grand Sadurengas dalam operasionalnya.

Tabel 10. Internal Factors Analysis Summary (IFAS)

\begin{tabular}{|l|c|c|c|}
\hline \multicolumn{1}{|c|}{ Indikator Variabel Internal } & Bobot & Rating & Score \\
\hline $\begin{array}{l}\text { 1. Hotel memiliki restoran dengan standar } \\
\text { interrnasional }\end{array}$ & 0,11 & 3 & 0,32 \\
\hline $\begin{array}{l}\text { 2. Fasilitas hotel berfungsi dengan baik seperti } \\
\text { mobil hotel }\end{array}$ & 0,05 & 1,5 & 0,08 \\
\hline $\begin{array}{l}\text { 3. Harga spesial untuk tamu yang berkunjung } \\
\text { lebih dari satu kali }\end{array}$ & 0,04 & 1 & 0,04 \\
\hline $\begin{array}{l}\text { 4. Jasa yang diberikan sesuai dengan harga } \\
\text { yang ditawarkan (nilai uang) }\end{array}$ & 0,07 & 2 & 0,14 \\
\hline $\begin{array}{l}\text { 5. Hotel dapat dicapai dengan mudah dari } \\
\text { berbagai lokasi }\end{array}$ & 0,11 & 3 & 0,32 \\
\hline
\end{tabular}




\begin{tabular}{|l|c|c|c|} 
6. Hotel memiliki promosi penjualan seperti & 0,14 & 4 & 0,57 \\
tarif promo khusus & 0,07 & 2 & 0,14 \\
\hline $\begin{array}{l}\text { 7. Hotel melakukan pengiklanan melalui } \\
\text { media internet }\end{array}$ & 0,13 & 3,5 & 0,44 \\
\hline 8. Penampilan karyawan sopan & 0,05 & 1,5 & 0,08 \\
\hline 9. Karyawan terampil menguasai bahasa asing & 0,13 & 3,5 & 0,44 \\
\hline $\begin{array}{l}\text { 10.Hotel menawarkan paket pernikahan } \\
\text { metel memiliki program seperti kelas }\end{array}$ & 0,04 & 1 & 0,04 \\
\hline $\begin{array}{l}\text { 12. Hotel bekerjasama dengan biro perjalanan } \\
\text { Total }\end{array}$ & 0,04 & 1 & 0,04 \\
\hline perjalanan & 0,04 & 1 & 0,04 \\
\hline
\end{tabular}

Sumber: Data diolah, 2015

Berdasarkan hasil analisis lingkungan internal seperti yang terlihat pada tabel di atas dapat diketahui bahwa hasil keseluruhan nilai tertimbang IFAS total sebesar 2,68. Hal ini mengindikasikan bahwa, Hotel Grand Sadurengas mempunyai kekuatan yang sedang dalam operasionalnya.

\section{Posisi Strategis Hotel Grand Sadurengas}

Setelah melakukan analisis pada lingkungan internal dan eksternal maka langkah selanjutnya adalah memindahkan skor nilai ke dalam matrik IFAS/EFAS. Nilai terbobot total untuk IFAS 2,68. Sedangkan skor nilai EFAS sebesar 3,39 sehingga posisi perusahaan pada matriks IFAS/EFAS disajikan pada gambar berikut.

Gambar 7. Matrik Strategi IE Hotel Grand Sadurengas

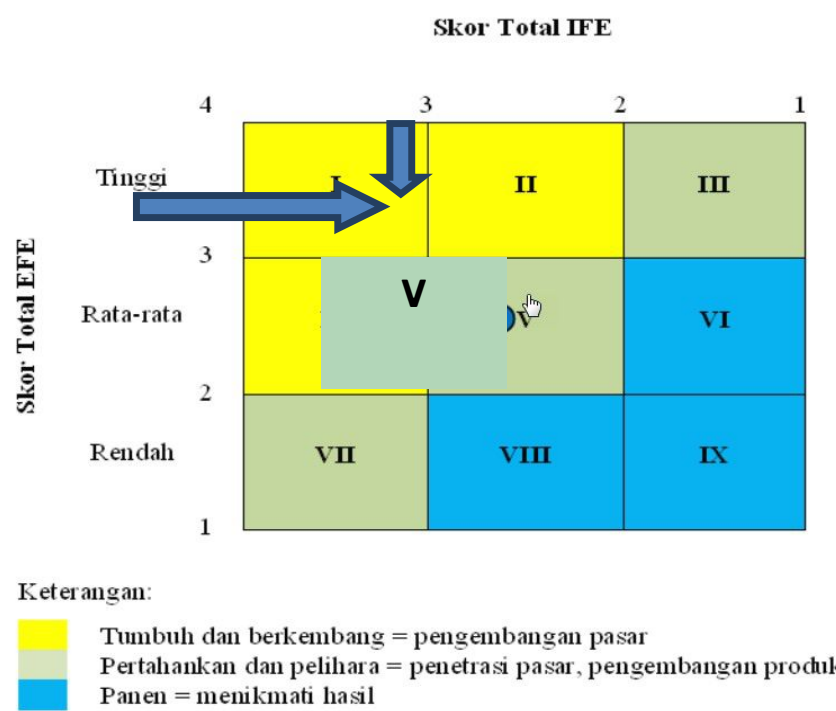

Sumber: Data diolah, 2015

Gambar di atas memperlihatkan posisi strategis Hotel Grand Sadurengas adalah grow and develop (tumbuh dan berkembang). Alternatif strategi yang dapat diterapkan kedepan pada 
masa mendatang yang terdiri atas strategi pengembangan pasar, penetrasi pasar dan pengembangan produk. Masing-masing strategi tersebut dapat dijabarkan seperti berikut:

1. Pengembangan Pasar

Penggunaan dasar strategi ini adalah menjadi hotel yang komersil di Kabupaten Paser dengan perluasan jaringan pasar. Segmentasi pasar yang dipilih oleh Hotel Grand Sadurengas yaitu kalangan menengah, dan atas. Perusahaan harus mampu memperluas pasar sampai wilayah baru seperti daerah Jawa. Cara untuk merambah pasar yang luas yaitu memperluas jaringan unit kerjasama dengan agen-agen tour \& travel di daerah Jawa sehingga calon pelanggan mendapatkan informasi yang akurat mengenai objek wisata serta akomodasinya (Hotel Grand Sadurengas).

2. Penetrasi Pasar

Penggunaan dasar penetrasi pasar adalah strategi yang dibuat untuk memperluas pasar dengan meningkatkan upaya-upaya pemasaran yang terdiri dari menyebarkan iklan dan penawaran produk jasa secara ekstensif dimana Hotel Grand Sadurengas menyediakan informasi produk dan jasa yang disediakan untuk calon pelanggan melalui internet karena penggunaan internet memiliki jaringan yang luas. Hal tersebut bertujuan untuk memperkenalkan produk dan jasa yang dimiliki oleh Hotel Grand Sadurengas kepada masyarakat luas yang ada di Indonesia maupun dunia. Selain itu, perusahaan harus mampu berkompetitif dalam penawaran produk dan jasa sebagaimana hotel lain yang memiliki kualitas yang terjamin.

3. Pengembangan Produk

Sebuah strategi yang mengupayakan peningkatan penjualan dengan cara memperbaiki atau memodifikasi produk atau jasa yang ada saat ini. Pengembangan produk biasanya membutuhkan pengeluaran yang besar untuk penelitian dan pengembangan.

Hotel Grand Sadurengas memiliki kekuatan lingkungan internal yang sedang dan kurang berpengaruh terhadap peluang eksternal. Dalam hal tersebut, penggunaan dasar strategi dalam pengembangan produk yaitu mengembangkan produk yang lama atau memberikan inovasi terbaru karena pada era globalisasi ini masyarakat cenderung mencari pelayanan terpadu dan tepat. Perusahaan yang bergerak dalam bidang perhotelan harus mampu memberikan kualitas produk dan jasa sesuai demi kepuasan pelanggan.

\section{E. Analisis Market Share}

Pada tahun 2014 ini jumlah hotel yang ada di Kabupaten Paser berjumlah 24 buah (termasuk Hotel Grand Sadurengas). Rata-rata market share untuk masing-masing hotel di Kabupaten Paser sebesar 4,17\% (100:24). Namun kalau dilihat dari keadaan hotel, maka Hotel Grand Sadurengas kondisinya lebih baik yang termasuk hotel kelas bintang tiga. Sementara hotel-hotel pesaingnya adalah kelas melati. Hal ini merupakan suatu keunggulan tersendiri dibanding dengan hotel pesaingnya. Dari keadaan tersebut tidaklah berlebihan kalau market share hotel Grand Sadurengas jelas lebih tinggi dari pesaingnya, yaitu sebesar $15 \%$. Penentuan $15 \%$ tersebut didasarkan pada rata-rata tingkat hunian kamar hotel di Kabupaten Paser, yaitu berkisar 21\% (Sumber: KPDA, 2013). Jadi kalau dibandingkan nilai market share terhadap jumlah kamar tersedia di Hotel Grand Sadurengas, maka hasilnya berkisar $21 \%$. Namun tidak menutup kemungkinan untuk masa yang akan datang market share nya berubah sesuai dengan perkembangan potensi pasar hotel di Kabupaten Paser serta strategi memenangkan persaingan yang dilakukan oleh Hotel Grand Sadurengas. Selanjutnya, penentuan market share Hotel Grand Sadurengas berdasarkan estimasi tingkat hunian kamar hotel di Kabupaten Paser seperti tabel berikut. 
Tabel 11. Proyeksi Market Share Tingkat Hunian Kamar

Hotel Grand Sadurengas

\begin{tabular}{|c|c|c|c|}
\hline No. & Tahun & Proyeksi Total Market & Market Share (15\%) \\
\hline 1. & 2014 & 126.228 & 7.056 \\
\hline 2. & 2015 & 219.478 & 7.608 \\
\hline 3. & 2016 & 349.261 & 8.159 \\
\hline 4. & 2017 & 515.574 & 8.711 \\
\hline 5. & 2018 & 718.419 & 9.262 \\
\hline 6. & 2019 & 957.796 & 9.814 \\
\hline 7. & 2020 & 1.233 .704 & 10.365 \\
\hline 8. & 2021 & 1.546 .143 & 10.917 \\
\hline 9. & 2022 & 1.895 .114 & 11.469 \\
\hline 10. & 2023 & 2.280 .616 & 12.020 \\
\hline 11. & 2024 & 2.702 .649 & 12.572 \\
\hline 12. & 2025 & 3.161 .214 & 13.123 \\
\hline 13. & 2026 & 3.656 .311 & 13.675 \\
\hline 14. & 2027 & 4.187 .938 & 14.226 \\
\hline 15. & 2028 & 4.756 .097 & 14.778 \\
\hline 16. & 2029 & 5.360 .788 & 15.329 \\
\hline 17. & 2030 & 6.002 .010 & 15.881 \\
\hline 18. & 2031 & 6.679 .763 & 16.433 \\
\hline 19. & 2032 & 7.394 .048 & 16.984 \\
\hline 20. & 2033 & 8.144 .864 & 17.536 \\
\hline 21. & 2034 & 8.932 .212 & 18.087 \\
\hline 22. & 2035 & 9.756 .091 & 18.639 \\
\hline 23. & 2036 & 10.616 .501 & 19.190 \\
\hline 24. & 2037 & 11.513 .443 & 19.742 \\
\hline 25. & 2038 & 12.446 .916 & 20.293 \\
\hline 26. & 2039 & 13.416 .920 & 20.845 \\
\hline 27. & 2040 & 14.423 .456 & 21.397 \\
\hline 28. & 2041 & 15.466 .524 & 21.948 \\
\hline 29. & 2042 & 16.546 .123 & 22.500 \\
\hline 30. & 2043 & 17.662 .253 & 23.051 \\
\hline 31. & 2044 & 18.814 .914 & 23.603 \\
\hline 32. & 2045 & 20.004 .107 & 24.154 \\
\hline 33. & 2046 & 21.229 .832 & 24.706 \\
\hline 34. & 2047 & 22.492 .088 & 25.257 \\
\hline 35. & 2048 & 23.790 .875 & 25.809 \\
\hline 36. & 2049 & 25.126 .193 & 26.361 \\
\hline 37. & 2050 & 26.498 .043 & 26.912 \\
\hline 38. & 2051 & 27.906 .425 & 27.464 \\
\hline 39. & 2052 & 29.351 .338 & 28.015 \\
\hline
\end{tabular}


Sumber: Data diolah, 2015

Proyeksi market share tingkat hunian kamar Hotel Grand Sadurengas selama 40 tahun. Lama estimasi tersebut didasarkan pada umur ekonomis hotel yang menurut Masyarakat Profesi Penilai Indonesia (MAPPI) umur ekonomis/manfaat bangunan hotel adalah 40 tahun. Untuk lebih jelasnya dapat dilihat pada tabel berikut.

Tabel 12. Umur Ekonomis/Manfaat Bangunan Hotel

\begin{tabular}{|c|l|c|}
\hline No & \multicolumn{1}{|c|}{ Bangunan Hotel/ Motel } & Umur Ekonomis \\
\hline 1 & Bangunan Vila tidak bertingkat & 30 tahun \\
\hline 2 & $\begin{array}{l}\text { Bangunan Vila/Hotel/Motel bertingkat } \leq \\
\text { 4 lantai }\end{array}$ & 40 tahun \\
\hline 3 & $\begin{array}{l}\text { Bangunan Vila/Hotel/Motel bertingkat } \geq \\
\text { 5 lantai }\end{array}$ & 50 tahun \\
\hline
\end{tabular}

Sumber: http://www.mappi.or.id/static-321-umur-ekonomis.html

\section{PEMBAHASAN}

\section{Analisis Penilaian Investasi}

a. Net Present Value (NPV)

Net Present Value (NPV) atau nilai bersih sekarang adalah kriteria investasi yang digunakan dalam mengukur apakah suatu proyek feasible atau tidak. Perhitungan NPV merupakan net benefit yang telah di diskon dengan menggunakan social opportunity cost of capital (SOCC). Apabila hasil NPV lebih besar dari 0 (nol) dikatakan bahwa proyek tersebut layak. Berikut Hasil NPV untuk proyek Pembangunan Hotel Sadurengas. Hasil perhitungan NPV menunjukkan nilai $>0$, ini berarti pembangunan Proyek Hotel Sadurenga layak dilaksanakan. Dalam perhitungan kriteria investasi, yang perlu mendapat perhatian adalah perkiraan cash in flows yang menyangkut dengan proyeksi, baik cost maupun benefit di masa yang akan datang. Dalam membuat perkiraan benefit harus dipertimbangkan berbagai variable yang mungkin mempengaruhi perkembangan proyek, seperti perubahan teknologi, perubahan selera konsumen dan lain sebagainya.

\section{b. Internal Rate Of Return (IRR)}

IRR adalah suatu tingkat discount rate yang menghasilkan NPV sama dengan 0 (nol). Apabila hasil perhitungan IRR lebih besar dari SOCC maka di katakan bahwa proyek tersebut layak. Untuk menentuka besarnya nilai IRR harus dihitung nilai NPV1 dan NPV 2 dengan cara coba-coba. Apabila NPV1 telah menunjukkan angka positif maka discount factor yang kedua harus lebih besar dari SOCC dan sebaliknya jika berada pada angka negative maka discount factor yang kedua berada di bawah SOCC.

Hasil perhitungan IRR menunjukkan bahwa nilai IRR 8\% dan nilai SOCC $6 \%$, hal ini menunjukkan bahwa IRR $>$ SOCC, dengan demikian proyek tersebut dinyatakan layak untuk di lanjutkan.

c. Payback Period (PP)

Pengertian dari Payback Period antara lain adalah, suatu periode yang diperlukan untuk menutup kembali pengeluaran investasi (initial cash investment) dengan 
menggunakan aliran kas. Semakin cepat dalam pengembalian investasi maka dapat dikatakan semakin baik proyek tersebut karena semakin lancar perputaran modal.

Berdasarkan hasil perhitungan dapat diketahui bahwa tingkat pengembalian investasi kurang lebih akan terjadi di tahun 2043 atau sekitar 30 tahun dengan asumsi diskon faktor $6 \%$ dan tingkat hunian $15 \%$.

\section{Analisis Break Event Point (BEP)}

Break Even Point atau BEP adalah suatu analisis untuk menentukan dan mencari jumlah barang atau jasa yang harus dijual kepada konsumen pada harga tertentu untuk menutupi biaya-biaya yang timbul serta mendapatkan keuntungan/ profit. BEP penting kalau kita membuat usaha agar kita tidak mengalami kerugian. Berdasarkan tabel 5.24 dapat dilihat bahwa BEP dari Hotel Sadurangas adalah 1.376 Kamar selama satu tahun, dan jika jumlah kamar yang tersedia terjual lebih dari 1.376 kamar maka pihak hotel tidak akan mengalami kerugian atau akan mendapatkan keuntungan.

Tabel 13 Perhitungan Break Event Point (BEP)

\begin{tabular}{|l|l|c|c|c|c|}
\hline KETERANGAN & $\begin{array}{c}<\text { BEP } \\
(1.000 \\
\text { kamar })\end{array}$ & $\begin{array}{c}\text { BEP }(\mathbf{1 . 3 7 6} \\
\text { kamar })\end{array}$ & $\begin{array}{c}>\text { BEP }(7.000 \\
\text { kamar })\end{array}$ & $\begin{array}{c}>\text { BEP }(15.000 \\
\text { kamar })\end{array}$ \\
\hline 1 & Pendapatan & $778,861,101$ & $1,071,712,875$ & $5,452,027,708$ & $11,682,916,518$ \\
\hline 2 & Biaya Variabel & $202,493,901$ & $278,631,607$ & $1,417,457,304$ & $3,037,408,510$ \\
\hline 3 & $\begin{array}{l}\text { Kontribusi } \\
\text { Margin }\end{array}$ & $576,367,201$ & $793,081,268$ & $4,034,570,404$ & $8,645,508,008$ \\
\hline 4 & Biaya Tetap & $793,232,078$ & $793,232,078$ & $793,232,078$ & $793,232,078$ \\
\hline & & - & $\mathbf{1 5 0 , 8 1 0}$ & $\mathbf{3 , 2 4 1 , 3 3 8 , 3 2 6}$ & $\mathbf{7 , 8 5 2 , 2 7 5 , 9 3 1}$ \\
\hline
\end{tabular}

Sumber: Data diolah, 2015

Perlu adanya pemahaman bahwa hasil audit itu sangat berpengaruh terhadap laporan keuangan periode berikutnya.

\section{SIMPULAN}

1. Berdasarkan analisis Competitive Profile Matrix (CPM) bahwa yang menjadi ancaman sedang bagi Hotel Grand Sadurengas adalah Hotel Indah dan Hotel Bumi Paser, karena total score berada pada rentang 2,61-3,40. Sedangkan untuk Hotel Lorus dan Tiara Hotel akan menciptakan peluang kecil bagi Hotel Grand Sadurengas, karena total score berada pada rentang 3,41-4,20. Selanjutnya Hotel Mariola akan menjadi peluang besar bagi Hotel Grand Sadurengas, karena total score berada pada rentang 4,21-5,00.

2. Berdasarkan analisis SWOT posisi strategis Hotel Grand Sadurengas adalah grow and develop (tumbuh dan berkembang). Alternatif strategi yang dapat diterapkan kedepan pada masa mendatang yang terdiri atas strategi pengembangan pasar, penetrasi pasar dan pengembangan produk. Masing-masing strategi tersebut dapat dijabarkan seperti berikut:

a. Pengembangan Pasar

Penggunaan dasar strategi ini adalah menjadi hotel yang komersil di Kabupaten Paser dengan perluasan jaringan pasar. Segmentasi pasar yang dipilih oleh Hotel Grand Sadurengas yaitu kalangan menengah, dan atas. Perusahaan harus mampu memperluas pasar sampai wilayah baru seperti daerah Jawa. Cara untuk merambah pasar yang luas yaitu memperluas jaringan unit kerjasama dengan agen-agen tour \& travel di daerah 
Jawa sehingga calon pelanggan mendapatkan informasi yang akurat mengenai objek wisata serta akomodasinya (Hotel Grand Sadurengas).

b. Penetrasi Pasar

Penggunaan dasar penetrasi pasar adalah strategi yang dibuat untuk memperluas pasar dengan meningkatkan upaya-upaya pemasaran yang terdiri dari menyebarkan iklan dan penawaran produk jasa secara ekstensif dimana Hotel Grand Sadurengas menyediakan informasi produk dan jasa yang disediakan untuk calon pelanggan melalui internet karena penggunaan internet memiliki jaringan yang luas. Hal tersebut bertujuan untuk memperkenalkan produk dan jasa yang dimiliki oleh Hotel Grand Sadurengas kepada masyarakat luas yang ada di Indonesia maupun dunia. Selain itu, perusahaan harus mampu berkompetitif dalam penawaran produk dan jasa sebagaimana hotel lain yang memiliki kualitas yang terjamin.

c. Pengembangan Produk

Sebuah strategi yang mengupayakan peningkatan penjualan dengan cara memperbaiki atau memodifikasi produk atau jasa yang ada saat ini. Pengembangan produk biasanya membutuhkan pengeluaran yang besar untuk penelitian dan pengembangan.

3. Hotel Grand Sadurengas memiliki kekuatan lingkungan internal yang sedang dan kurang berpengaruh terhadap peluang eksternal. Dalam hal tersebut, penggunaan dasar strategi dalam pengembangan produk yaitu mengembangkan produk yang lama atau memberikan inovasi terbaru karena pada era globalisasi ini masyarakat cenderung mencari pelayanan terpadu dan tepat. Perusahaan yang bergerak dalam bidang perhotelan harus mampu memberikan kualitas produk dan jasa yang sesuai dengan keinginan demi kepuasan pelanggan.

4. Rata-rata market share untuk masing-masing hotel di Kabupaten Paser sebesar 4,17\% (100:24). Namun kalau dilihat dari keadaan hotel, maka Hotel Grand Sadurengas kondisinya lebih baik yang termasuk hotel kelas bintang tiga. Sementara hotel-hotel pesaingnya adalah kelas melati. Hal ini merupakan suatu keunggulan tersendiri dibanding dengan hotel pesaingnya. Dari keadaan tersebut tidaklah berlebihan kalau market share hotel Grand Sadurengas jelas lebih tinggi dari pesaingnya, yaitu sebesar 15\%. Penentuan $15 \%$ tersebut didasarkan pada rata-rata tingkat hunian kamar hotel di Kabupaten Paser, yaitu berkisar 21\% (Sumber: KPDA, 2013). Jadi kalau dibandingkan nilai market share terhadap jumlah kamar tersedia di Hotel Grand Sadurengas, maka hasilnya berkisar 21\%. Namun tidak menutup kemungkinan untuk masa yang akan datang market share nya berubah sesuai dengan perkembangan potensi pasar hotel di Kabupaten Paser serta strategi memenangkan persaingan yang dilakukan oleh Hotel Grand Sadurengas.

5. Dari hasil analisis kelayakan (Payback Period, NPV dan IRR) maka dapat dikatakan bahwa investasi pada Hotel Grand Sadurengas layak untuk diteruskan, namun dengan tingkat keuntungan yang rendah dan pengembalian modal yang cukup lama yaitu 30 tahun.

6. Dari hasil analisis BEP bahwa tingkat penjualan kamar Hotel Grand Sadurengas agar tidak mengalami kerugian yaitu minimal sebesar 1.376 unit kamar setiap tahunnya. 


\section{SARAN}

1. Dalam hal aspek pasar Hotel Grand Sadurengas masih harus banyak berbenah terutama lingkungan internalnya. Hasil analisis SWOT menyebutkan bahwa Hotel Grand Sadurengas memiliki kekuatan lingkungan internal yang sedang dan kurang berpengaruh terhadap peluang eksternal. Untuk itu, hal yang harus dilakukan adalah:

a. Pelatihan karyawan dalam hal pelayanan prima.

b. Perbanyak jaringan kerjasama dengan agen-agen perjalanan yang ada di Kabupaten Paser dan yang ada di Jawa, kalau perlu memberikan fee bagi agenagen perjalanan yang dapat mengarahkan wisatawan ataupun tamu lainnya ke Hotel Grand Sadurengas.

c. Membuat brosur yang menarik dan diberikan/dititipkan pada agen-agen perjalanan.

d. Menjalin hubungan dengan Pemerintah Daerah Kabupaten Paser, lembaga pendidikan tinggi, perusahaan swasta dalam hal penyediaan tempat pelatihan, workshop, seminar dan kegiatannya lainnya dengan harga atau diskon khusus. Pasar ini dapat merebut market share dengan penetrasi pasar kelas menengah ke atas.

e. Harus aktif dalam iklan melalui internet dengan membuat website sendiri. Hal ini penting karena di saat wisatawan/tamu dari luar daerah yang tidak mengenal Kabupaten Paser (yang baru pertama kali) tentunya akan mencari akomodasi melalui internet.

f. Meningkatkan promosi dan pemasaran wisata ditempat-tempat strategis seperti di bandara dan di tempat-tempat pelayanan umum, serta menjalin kerja sama dengan PEMDA, SKPD, Pemerintah Provinsi, dan Pemerintah Pusat.

g. Dalam hubungannya kerjasama dengan PEMDA dan SKPD, diketahui bahwa disekitar hotel juga ada 7 perkantoran, ada Rumah Sakit serta akan dibangunnya stadion dekat hotel, yang kesemuanya itu dapat dilakukan kerjasama dengan pihak terkait tersebut, dimana kalau ada tamu dari luar kota diharapkan pihak terkait tersebut dapat mengarahkan tamunya untuk menginap di Hotel Sadurengas. Tentunya pihak hotel juga harus mengerti kalau ada pihak terkait tersebut membawa tamu ke hotel, maka pihak hotel juga memberikan sebuah rangsangan berupa fee atau semacamnya.

h. Telaga Ungu yang ada didepan hotel airnya kotor. Hal tersebut tentunya kurang menarik bagi pengunjung hotel. Untuk itu perlu diupayakan pembersihan air telaga tersebut agar menjadi bersih dan bening, sehingga menarik perhatian pengunjung hotel.

i. Yang terakhir, adalah harga kamar atau jasa lainnya seperti makan dan sewa ruangan. Apapun upaya yang dilakukan pada poin-poin sebelumnya kalau harganya tidak bisa bersaing semuanya menjadi tidak berguna. Untuk itu perlu mengkaji ulang strategi kebijakan harga yang diterapkan Hotel Sadurengas. Ada berbagai ragam strategi harga. Masing-masing strategi digunakan di situasi yang berbeda. Beberapa hal yang harus dipertimbangkan ketika memilih strategi terbaik adalah biaya hotel; penjualan jangka pendek dan panjang serta target profit; aktfitas kompetitorl dan nilai life time kustomer. salah satu strategi harga adalah competitive pricing. Dalam competitive pricing, hotel melihat harga yang dikenakan kompetitor dan menggunakannya sebagai benchmark untuk menetapkan harga produk hotel. Strategi positioning hotel dan kompetitor akan menentukan apakah harga Anda setara, sedikit dibawahnya, atau sedikit diatas pesaing. 
2. Tanpa mengurangi makna dan sejarah penamaan hotel "SADURENGAS" kurang familier di masyarakat karena agak susah penyebutannya. Berdasarkan hal tersebut dapat dipikirkan dengan memberi alternatif penggantian nama misalnya, Hotel Grand Violet, Hotel Telaga Unggu, atau lainnya. Hal ini dikarenakan kami melihat bahwa warna ungu menjadi maskot Kabupaten Paser.

3. Dalam hal aspek keuangan, Hotel Grand Sadurengas diharapkan dapat menggenjot tingkat pendapatan hunian kamar dan pendapatan lainnya. Hal ini kalau dilihat dari hasil analisis bahwa tingkat keuntungan yang masih rendah yaitu berkisar 1-8\% (lihat lampiran perhitungan BEP). Kalau dana pembangunan hotel sebesar Rp. 200.000.000.000,- disimpan di bank dalam bentuk deposito maka akan menghasilkan keuntungan kurang lebih 6\% setahun, itupun tidak ada risiko, sedangkan investasi hotel ada risiko dengan tingkat keuntungan yang kurang lebih sama.

4. Pendapatan hotel didasarkan pada market share yang kemungkinan bisa diperoleh yaitu sebesar 15\%. Tentunya untuk meningkatkan tingkat keuntungan, mau tidak mau Hotel Grand Sadurengas harus berusaha keras merebut market share di atas 15\%. Caranya adalah seperti yang disebutkan dalam rekomendasi aspek pasar yaitu pengembangan pasar, penetrasi pasar, dan pengembangan produk. Hal ini tentunya juga akan mempercepat tingkat pengembalian dana investasi hotel.

5. Pengelolaan hotel dengan membayar/menggaji manajer profesional adalah salah satu alternatif, dengan resiko kepentingan pengelola yang lebih kecil. Karena dengan pengelolaan hotel oleh pihak ketiga berdasarkan teknik bagi hasil, kemungkinan pengelola tersebut kalau tidak terawasi dengan baik sangat mungkin untuk melakukan berbagai tindakan agar mendapatkan porsi laba yang lebih tinggi bagi pengelola.

6. Berdasarkan Peraturan Menteri Dalam Negeri No 22 Tahun 2009 tentang Petunjuk Teknis Tata Cara Kerjasama Daerah dalam BAB III Pasal 3, ayat 2, dapat dilakukan kerjasama dengan pihak ketiga dengan cara Bupati membentuk Tim Koordinasi Kerja Sama Daerah (TKKSD). Dan selanjutnya secara detail Kerja Sama Daerah dengan Badan Hukum atas Prakarsa Daerah diatur dalam Lampiran 1 Peraturan Menteri Dalam Negeri No 22 Tahun 2009.

7. Dalam meningkatkan kunjungan wisatawan ke Kabupaten Paser yang akan berdampak langsung terhadap tingkat hunian hotel, maka Dinas Pariwisata Seni dan Budaya Kabupaten Paser mengupayakan agar terciptanya pembangunan pariwisata berkelanjutan, dimana pembangunan pariwisata berkelanjutan tersebut harus menganut tiga prinsip, yaitu: 1) Ecological sustainability; 2) Social and cultural sustainability; dan 3) Economic sustainability, baik untuk generasi yang sekarang maupun generasi yang akan datang. Pembangunan pariwisata berkelanjutan diartikan sebagai proses pembangunan kepariwisataan yang tidak mengesampingkan kelestarian sumber daya yang dibutuhkan untuk pembangunan di masa yang akan datang. Dalam pembangunan pariwisata berkelanjutan, penekanan keberlanjutan bahkan tidak cukup dengan keberlanjutan ekologis dan keberlanjutan pembangunan ekonomi. Yang tidak kalah pentingnya adalah keberlanjutan kebudayaan, karena kebudayaan merupakan salah satu 'sumber daya' yang sangat penting dalam pembangunan kepariwisataan, mengingat Kabupaten Paser sebagai salah satu daerah tujuan wisata yang mengembangkan pariwisata budaya sebagai daya tariknya.Untuk itu diperlukan strategi untuk meningkatkan kunjungan wisatawan, yaitu peningkatan sarana dan prasarana transportasi untuk menjangkau obyek masih mengalami kesulitan. Sasaran yang ingin dicapai dari strategi pariwisata tersebut adalah: 
a. Meningkatkan pemeliharaan terhadap objek-objek wisata dan menggali potensi kepariwisataan lainnya.

b. Mengembangkan sarana dan prasarana pendukung objek wisata, antara lain perbaikan akses jalan menuju objek-objek wisata alam dan wisata agro.

c. Membangun kemitraan dalam pengelolaan objek wisata dengan masyarakat sekitar objek wisata.

d. Meningkatkan pembinaan kepada pengrajin cindera mata, terutama pada masyarakat di sekitar objek wisata.

e. Meningkatkan promosi dan pemasaran wisata.

Pada penelitian ini penentuan/pendistribusian bagi hasil difokuskan pada metode Profit Sharing. Dalam metode tersebut pemodal (Pemerintah Kabupaten Paser) dengan Pengelola (Operator Hotel) menentukan persentasi (nisbah) Profit Sharing. Untuk penentuan persentase (nisbah) bagi hasil dengan metode profit sharing tidak ada ukuran yang pasti. Itu semua tergantung kesepakatan antara kedua belah pihak. Namun pada umumnya adalah 60:40 (mengacu pada bank syariah). Artinya setelah keuntungan bersih perusahaan ditentukan, maka bagian keuntungan untuk pemodal (Pemerintah Kabupaten Paser) sebesar 60\% dari keuntungan bersih, sedangkan sisanya (40\%) merupakan bagian keuntungan untuk pengelola (operator hotel). Selanjutnya, setelah ada kesepakatan tentang teknis bagi hasil, maka semua kesepatakan yang ada dibuatkan naskah kerjasamanya di depan notaris. Perlu diketahui bahwa untuk meminimalisasi risiko bagi Investor selaku pemilik modal, umumnya dalam perjanjian Kerjasama Bagi hasil, disisipkan klausul yang menyatakan Pengelola selalu memberikan laporan kerja dan laporan keuangan kepada pemilik modal secara rutin. Sehingga, pemodal dapat mengetahui perkembangan usahanya.

\section{Daftar Pustaka}

Andri, Rachmawati dan Hanung Triatmoko. 2007. Analisis Faktor-Faktor yang Mempengaruhi Kualitas Laba dan Nilai Perusahaan. Artikel Simposium Nasional Akuntansi (SNA) X, Makasar.

Black, B.S, W. Kim, H. Jang, dan K.S. Park. 2002. Does Corporat Governance Affect Firm Value? Evidence from Korea. Finance Working Paper, No.103, http://www.ssrn.com.

Brigham, E.F, Houston, J.F. 2001. Manajemen Keuangan. Buku 1 dan 2. Edisi Kedelapan. Jakarta: Erlangga.

David, F. 2000. Concepts of Strategic Management. 12 th Edition. Prentice Hall inc.

Gusriani dan Wiguna, Putu Artama. 2013. Analisa Investasi Hotel Axana (Ex Ambacang) Padang. Jurnal Teknik Pomits Vol. 2, No. 1, (2013) ISSN: 2337-3539 (2301-9271 Print). Hal. C53C57.

Haming, M, Basalamah S. 2003. Studi Kelayakan Investasi: Proyek dan Bisnis. Jakarta: PPM.

Husnan, S dan Muhamad. 2000. Studi Kelayakan Proyek. Edisi Keempat. Yogyakarta: UPP STIM YKPN.

Husnan, S. 2000. Manajemen Keuangan: Teori dan Penerapan (Keputusan Jangka Panjang). Jilid 1 dan 2. Edisi Empat, Yogyakarta: BPFE.

Khrisna, dkk. 2013. Analisis Capital Recovery Investasi Pada Proyek Condotel The Jimbaran View. Jurnal Ilmiah Elektronik Infrastruktur Teknik Sipil, Volume 2, No. 1, Pebruari 2013. http://www.scribd.com (Diakses 11 Juni 2014).

Kotler, P. 2009. Manajemen Pemasaran. Edisi 13 Jilid 1. Jakarta: Penerbit Erlangga.

Kodrat, David Sukardi. 2009. Manajemen Distribusi. Edisi Pertama, Graha Ilmu, Yogyakarta. 
Muhammad. 2001. Teknik Perhitungan Bagi Hasil di Bank Syari'ah, Yogyakarta: UII Press.

Nurcholis, Hanif. 2007. Teori dan Praktik Pemerintahan dan Otonomi Daerah, Jakarta: Gramedia.

Pass, Cristopher et al. 1997. Kamus Lengkap Ekonomi. Cet. Ke-2. Jakarta: Erlangga.

Pkf Consulting. 2006. Market Feasibility Study Proposed Hotel / Convention Center.

Rangkuti, F. 2004. Analisis SWOT Teknik Membedah Kasus Bisnis. Jakarta: Gramedia.

Rika, Nurlela dan Islahuddin. 2008. Pengaruh Corporate Social Responsibility Terhadap Nilai Perusahaan dengan Prosentase Kepemilikan Manajemen Sebagai Variabel Moderating, Simposium Nasional Akuntansi XI Pontianak.

Rofiq, Ahmad. 2004. Fiqih Kontekstual dari Normatif ke Pemaknaan Sosial, Yogyakarta: Pustaka Pelajar.

Sartono. 2001. Manajemen Keuangan Teori dan Aplikasi, Edisi Keempat, Yogyakarta, BPFE.

Satoto, R. 2005. Analisis Kelayakan Investasi Apotek Kimia Farma 82 Kartika Plaza.

Sinar Grafika. 1983-2000. Undang-undang Republik Indonesia Nomor 17 tentang Perubahan Ketiga atas Undang-undang No 7 Tahun 2000 tentang Pajak Penghasilan.

Sofyan. 2003. Studi Kelayakan Bisnis. Edisi Pertama. Yogyakarta: Graha Ilmu.

Sucipto, A. 2010. Studi Kelayakan Bisnis - Analisis Integratif dan Studi Kasus. Cetakan 1. Malang: Aditya Media.

Sugita, I Nyoman. 2011. Kajian Kelayakan Finansial Pembangunan Gedung Parkir Universitas Udayana Di Jalan Sudirman Denpasar. Tesis. Program Pascasarjana Universitas Udayana Denpasar 2011.

Sulistyo- Basuki. 2010. Metode Penelitian. Jakarta: Penaku.

Supriyanto. 2010. Pemasaran Industri Jasa Kesehatan. Yogyakarta: CV Andi Offset.

Suratman. 2001. Studi Kelayakan Proyek - teknik dan prosedur penyusunan laporan, Edisi Pertama, Yogyakarta, J\&J Learning.

Susanti. 2010. Analisis Faktor-Faktor Yang Berpengaruh Terhadap Nilai Perusahaan (Studi Kasus Pada Perusahaan Go Public Yang Listed Tahun 2005-2008). Fakultas Ekonomi Universitas Diponegoro Semarang.

Sutojo, S. 2002. Studi Kelayakan Proyek: Konsep, Teknik \& Kasus. Cetakan 2. Jakarta: Damar Mulia Pustaka.

Syamsudin. 2002. Manajemen Keuangan Daerah. Jakarta: PT RajaGrafindo Persada.

Umar, H. 2002. Metode Riset Bisnis. Jakarta : PT Gramedia Pustaka Utama.

Warsika, Putu Dharma. 2009. Studi Kelayakan Investasi Bisnis Properti (Studi Kasus: Ciater Riung Rangga). Jurnal Ilmiah Teknik Sipil Vol. 13, No. 1, Januari 2009. Hal. 32-38.

Wijaya, Sri. 2013. Studi Kelayakan Investasi Hotel Best Western Premier Kapasitas Hotel Bintang Tiga Di Surakarta. Digital Library Universitas Sebelas Maret. http://digilib.uns.ac.id (Diakses 10 Juni 2013).

Yoeti. 2004. Strategi Pemasaran Hotel. Jakarta: PT Gramedia Pustaka Utama. . 2006. Tours and Travel Management. Edisi Tujuh. Jakarta: PT Prandnya Paramita. 